\title{
A warmer but drier Marine Isotope Stage 11 during the past 650 ka as revealed by the thickest loess on the western Chinese Loess Plateau
}

\author{
SHI Peihong ${ }^{1,2^{*}}$, YANG Taibao ${ }^{3}$, TIAN Qingchun ${ }^{4}$, LI Chengxiu ${ }^{5}$ \\ ${ }^{1}$ College of Tourism and Environment, Shaanxi Normal University, Xi' an 710119, China; \\ ${ }^{2}$ State Key Laboratory of Cryospheric Sciences, Cold and Arid Regions Environmental and Engineering Research Institute, \\ Chinese Academy of Sciences, Lanzhou 730000, China; \\ ${ }^{3}$ Institute of Glaciology and Ecogeography, College of Earth and Environmental Sciences, Lanzhou University, Lanzhou 730000, China; \\ ${ }^{4}$ College of Geographical Science, Shanxi Normal University, Linfen 041000, China; \\ ${ }^{5}$ Remote Sensing Laboratories, Department of Geography, University of Zurich-Irchel, Winterthurerstrasse $190 \mathrm{CH}-8057$ \\ Zurich, Switzerland
}

\begin{abstract}
Marine Isotope Stage 11 (MIS 11; ca. 423-362 ka) is generally considered to be the best analogue for the present interglacial (Holocene), and investigation of it will improve our understanding of current climate variability and assist in predictions of future climate change. However, many recent studies primarily focus on the structure and duration of MIS 11. Little research has focused on climate warmth and stability recorded in the Chinese loess-paleosol sequences (LPS) during the S4 paleosol formation (equivalent to MIS 11). On the basis of previous work, this study presents a high-resolution record (ca. $75 \mathrm{a} / \mathrm{cm}$ ) that spans from MIS 1 to MIS 15, as preserved in the thickest known Jingyuan loess section on the western Chinese Loess Plateau (CLP). This LPS is almost $165 \mathrm{~m}$ thick and was sampled from the upper part of L6 to the modern soil at $2-\mathrm{cm}$ depth intervals. Measurements of magnetic susceptibility, mean grain size and $>63 \mu \mathrm{m}$ particle content, carbonate content, total organic carbon, and soil color of samples were made to reconstruct the paleoclimate variation, and a grain-size age model was used to constrain the chronological framework. The primary results show that a generally warm-humid climate dominated the S4 paleosol development, but the climate condition was extremely unstable during the whole of MIS 11. Two obviously different climate regimes controlled the MIS 11 climate variation: the early part of MIS 11 was extremely warm and stable, but the latter part was relatively cool (non-glacial) and unstable. This climate pattern was consistent with records on the central CLP and wavelet analysis suggested that it was forced by the $65^{\circ} \mathrm{N}$ insolation variability modulated by a quasi-100-ka cycle. In addition, a multi-proxy comparative study on the climate conditions during S0 to S5 paleosol development indicates that the period of S4 development might be the warmest interglacial of the past $650 \mathrm{ka}$. However, the climate condition during S4 development was not the most humid episode as recorded in Xifeng and Luochuan loess sections on the central CLP. On the contrary, it was drier than both the MIS 15 and the present interglacial on the western CLP, which is somewhat similar to the present climate pattern on the central CLP.
\end{abstract}

Keywords: Marine Isotope Stage 11; loess-paleosol; interglacial; Holocene; paleoclimate; wavelet analysis

Citation: SHI Peihong, YANG Taibao, TIAN Qingchun, LI Chengxiu. 2016. A warmer but drier Marine Isotope Stage 11 during the past $650 \mathrm{ka}$ as revealed by the thickest loess on the western Chinese Loess Plateau. Journal of Arid Land, 8(3): 315-330. doi: 10.1007/s40333-016-0123-7

*Corresponding author: SHI Peihong (E-mail: shipeih@hotmail.com)
Received 2015-06-30; revised 2015-10-08; accepted 2015-11-16
C Xinjiang Institute of Ecology and Geography, Chinese Academy of Sciences, Science Press and Springer-Verlag Berlin Heidelberg 2016 
As the scientific evidence for global warming continues to grow (Stocker et al., 2013), increasing emphasis has been placed on studying times in the geological past when the climate was similar to, or warmer than, the present, to help improve the understanding of how the present climate may evolve without human intervention (Candy et al., 2014). A current area of interest is the complexity and structure of Marine Isotope Stage 11 (MIS 11; ca. 423-362 ka), because of the similarities of the orbitally driven insolation (Loutre and Berger, 2003; Candy et al., 2014) and the atmospheric $\mathrm{CO}_{2}$ levels (EPICA Community Members, 2004; Pol et al., 2011) to those during the Holocene. These similarities make MIS 11 the best analogue for the present interglacial and future climate scenarios (Howard, 1997; Tzedakis, 2010; Candy et al., 2014). Previous studies have shown that MIS 11 was the longest and warmest interglacial of the past 500 ka (Droxler et al., 2003a; Loutre and Berger, 2003; Desprat et al., 2005), and was characterized by the highest amplitude deglacial warming of the previous 5 Ma (Mix et al., 1995; Howard, 1997). However, this has been challenged more recently by several authors who claimed that this interglacial was not substantially warmer than today; on the contrary, they suggested that it was somewhat colder than the present (Bauch et al., 2000; Hodell et al., 2000; Candy et al., 2014). Moreover, several recent studies have also proposed that the apparent stability of MIS 11 was in fact somewhat more complex (Bauch et al., 2000; Hodell et al., 2000; Ashton et al., 2008; Candy et al., 2014). Thus, more detailed studies of long-term and continuous geological records around the world are urgently required.

Previously, problems with the accuracy and resolution of dating have seriously hampered studies that aimed to decipher climate variations during MIS 11 by using terrestrial sediments. However, one notable exception is the Chinese loess-paleosol sequence (LPS), which was deposited continuously and has yielded one of the most complete and sensitive terrestrial records of the past 2.6 Ma (Ding et al., 2002; Hao et al., 2012). In particular, the LPS is stratigraphically well-correlated across the entire Chinese Loess Plateau (CLP) and is also correlated to the marine isotope stages (Heslop et al., 2000; Ding et al., 2002), offering a rare opportunity to study the climatic and environmental conditions during the MIS 11. The paleosol S4 is well-correlated with MIS 11, which is commonly regarded as one of the most strongly developed soils (Guo et al., 2000; Hao and Guo, 2005), and a widely accepted marker of loess stratigraphy in the Chinese loess (Liu, 1985; Ding et al., 2002), especially on the western part of the CLP. Ding et al. (1995) have suggested the $\mathrm{S} 4$ soil contains a stronger Bt horizon (dark red color, fine sub-angular blocky structure, substantial coatings on the structural faces, and no carbonate nodules) in the Chinese loess, indicating that the climate was warm and humid. Guo et al. (1998) also found that the free iron oxide $\left(\mathrm{Fe}_{\mathrm{d}}\right)$ to total iron $\left(\mathrm{Fe}_{\mathrm{t}}\right)$ ratio $\left(\mathrm{Fe}_{\mathrm{d}} / \mathrm{Fe}_{\mathrm{t}}\right)$ was higher in the S4 paleosol than in the S5 unit in the Changwu $(\mathrm{CW})$ loess section, and concluded that the weathering degree during MIS 11 was greater than that during the MIS 13 and MIS 15 intervals. Subsequently, Guo et al. (2000) further inferred that the paleosol S4 was formed under extremely warm and humid climate conditions, and represented a period of strengthened East Asian summer monsoon (EASM) and abnormally weakened East Asian winter monsoon (EAWM) over the CLP. Wavelet analysis also confirmed that the paleoclimate was relatively stable during the formation of S4 in the Luochuan (LC) loess section (Wu and $\mathrm{Lu}, 2012$ ). In addition, Guo et al. (1998) concluded that the S4 soil represented the warmest period of the past 1.2 Ma and formed under sub-tropical and semi-humid climate conditions, on the basis of paleopedological, geochemical and magnetic susceptibility (MS) variations in three loess sections (Xifeng (XF), CW, and Weinan (WN); see Fig. 1a) on the central CLP. A similar result was obtained at the Lanzhou (LZ) loess section on the western CLP by Chen et al. (2014), who found that the S4 paleosol is the best-developed soil of the past 1.4 Ma and has higher MS values than the S5 unit. In particular, Holly pollen (Ilex sp.) was detected in the S4 paleosol in this section (Chen and Zhang, 1993), further suggesting that the LZ area was located at the northern edge of the subtropical zone during the MIS 11 interglacial, rather than in the current semi-arid temperate zone.

In contrast, using geochemical, sedimentological, and MS data from the Jiaodao (JD) section (30 km north of LC; Fig. 1a), Vidic et al. (2003) found that the S4 paleosol is just a well-developed paleosol unit, but does not reflect unusually warm or stable conditions during its 
development. Furthermore, It has been recently suggested that unstable climatic conditions existed during the development of the S4 paleosol and the climate was only warm-humid, by using terrestrial mollusk assemblages in the XF and LC loess sections (Wu et al., 2007; Wu and $\mathrm{Lu}, 2012)$. And at least five extreme climatic events were identifiable during S4 soil development (Wu et al., 2007; Wu and $\mathrm{Lu}, 2012$ ). Clearly, much uncertainty remains regarding climate stability during the S4 paleosol development, as well as whether the climate was warmer or colder during MIS 11 than the present. This uncertainty probably relates to the distinctly different temporal resolution of the S4 paleosol in the studied loess sections. On the central CLP, the deposition rate was lower, but the pedogenesis intensity was higher. Thus, the loess and paleosol horizons are thin and the climatic record may have been "erased and mixed", so that the subtle variations of the paleoclimatic record are not well preserved. In contrast, on the western CLP, the loess accumulation rate was extremely higher, but the pedogenesis intensity was relatively weaker. So, the stratigraphic record remains undisturbed (Derbyshire et al., 1998). Therefore, the key to interpreting the above-mentioned questions is to select thicker loess deposits, such as the loess section on the western CLP, which may uncover a more detailed climatic signal than those on the central CLP and could help us to understand the climate stability and warmth during MIS 11.

The Jingyuan (JY) section is the thickest known loess deposit and the most complete record on the western CLP (Yue et al., 1991; Sun et al., 2006; Shi et al., 2013). Moreover, it is located in the transitional zone between monsoon and non-monsoon areas (Fig. 2), where it is very sensitive to the regional and global climate change (Sun et al., 2006). Therefore, this is an ideal place to investigate paleoclimate change. In this study, we sampled the upper part of the JY loess-paleosol sequence (S0-L6: ca. $165 \mathrm{~m}$ thick) and documented the sub-millennial climate variability during the development of the S4 paleosol. The aims of this study are: (1) to provide a detailed insight into the climatic variability during MIS 11 using high-resolution temporal datasets; (2) to determine whether the MIS 11 climate was warmer or cooler than the present interglacial; and (3) to identify and discuss the climate stability and possible forces of climate variability during the MIS 11 interglacial.

\section{Materials and methods}

\subsection{Stratigraphy and sampling}

The JY loess section $\left(36^{\circ} 22^{\prime} 45^{\prime \prime} \mathrm{N}, 1^{\circ} 4^{\circ} 37^{\prime} 26^{\prime \prime} \mathrm{E} ; 2,120 \mathrm{~m}\right.$ asl) is a typical LPS (Heslop et al., 1999; Chen et al., 2003; Sun et al., 2006; Shi et al., 2013) on the western CLP (Fig. 1a), which is situated to the northeast of the Tibetan Plateau (TP) and in the transition zone between monsoon and non-monsoon areas (Fig. 2). The sample site lies about $80 \mathrm{~km}$ to the south of the modern Tengger Desert and about $28 \mathrm{~km}$ south of JY town (Fig. 1b). In this region, the modern climate is much drier than that in other parts of the CLP. The annual mean temperature (AMT) and mean annual precipitation (MAP) are $8.3^{\circ} \mathrm{C}$ and $275 \mathrm{~mm}$, respectively. The outcrop is exposed on the sixth terrace of the Yellow River in the JY Basin and has a thickness of about $505 \mathrm{~m}$ (Yue et al., 1991). The Holocene soil (S0) and the last interglacial paleosol (S1) at this site were described by Heslop et al. (1999) and Chen et al. (1999, 2003).

In this study, we sampled the uppermost 165-m loess-paleosol (Fig. 1c), including the whole of the Holocene soil (S0) and Malan loess (L1), and most of the Lishi loess (S1-L6). The loess-paleosol units (Figs. 2c-d) and their exact boundaries were further determined by their MS as described in previous work (Shi et al., 2012, 2013), which is higher in paleosols and lower in the intervening loess layers. There are fifteen paleosol units in total, each being identified by its light reddish color (e.g. S4; Fig. 2e) and higher MS values. All paleosol complexes (S1-S5) are composed of at least three sub-paleosols formed within two thin loess horizons (Yue et al., 1991; Shi et al., 2013). The stratigraphic sequence in the JY loess section is generally correlated well with the LPS on the central CLP, but has a much higher resolution. The thickness of each paleosol layer is given in Table 1. The total thickness of loess deposits from the upper part of L6 to S0 is almost three times thicker than those of previously reported sections in the southern and central 
CLP (e.g. XF, LC and WN sections) (Sun et al., 2006), which allows a much higher resolution evaluation of MIS 11 variability than has been possible in previous studies.

To obtain samples of fresh sediments, we removed the surficial weathered layer to a depth of 1 m. Samples intended for MS, grain size (GS), total organic carbon (TOC) and carbonate $\left(\mathrm{CaCO}_{3}\right)$ content analysis were collected at $10-\mathrm{cm}$ intervals, whereas samples for soil color $\left(\mathrm{L}^{*} \mathrm{a}^{*} \mathrm{~b}^{*}\right)$ analysis were collected at $2-\mathrm{cm}$ intervals. Each bulk sample contained at least $100 \mathrm{~g}$ of material, and 8,250 samples were collected in total.
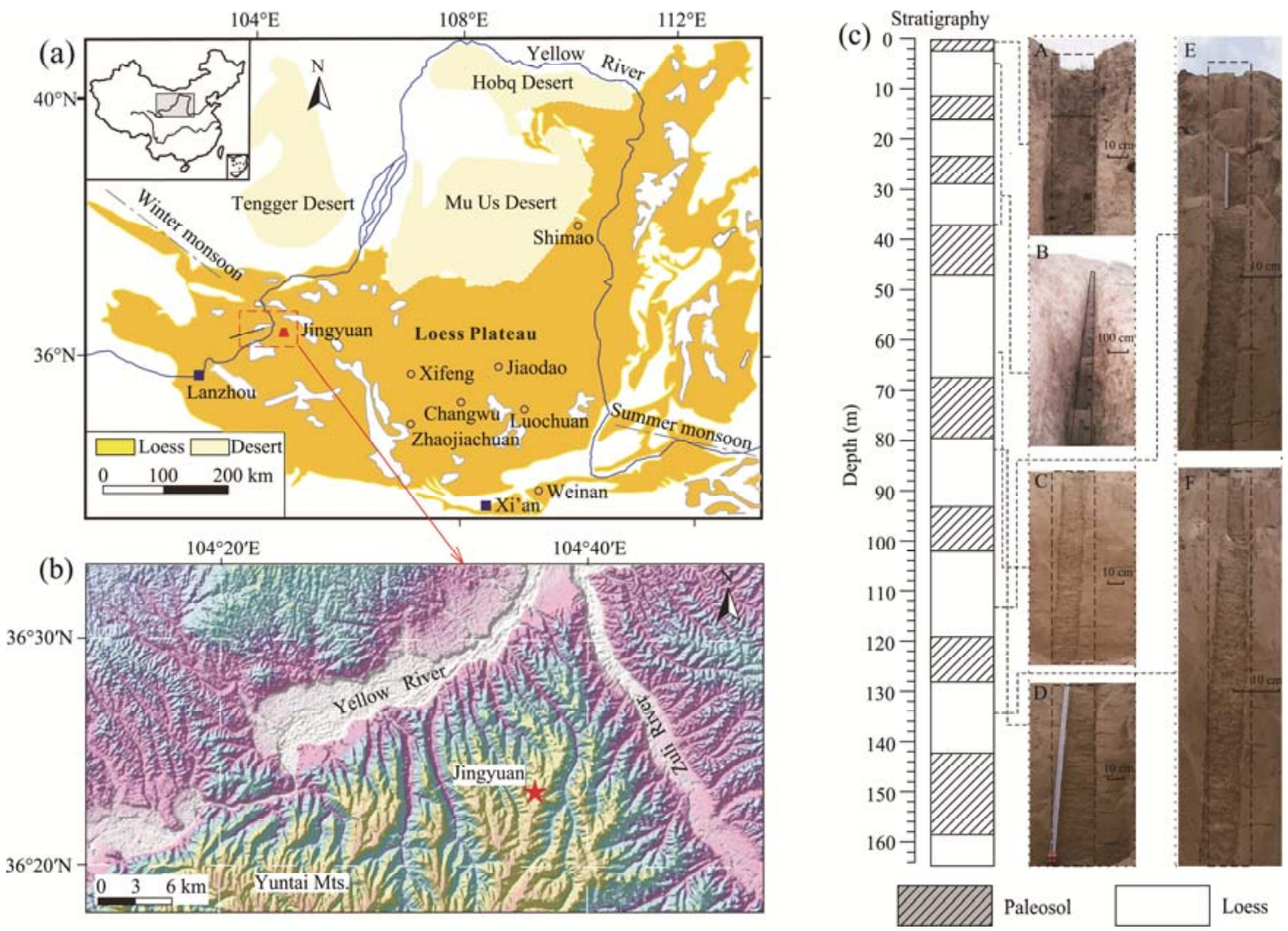

Fig. 1 Sketch map of the Chinese Loess Plateau (CLP) showing the locations of the loess sections mentioned in the text (a); topographic map of the area surrounding the Jingyuan (JY) loess section (b); loess-paleosol sequences and photographs of sampling at the JY loess section (c)

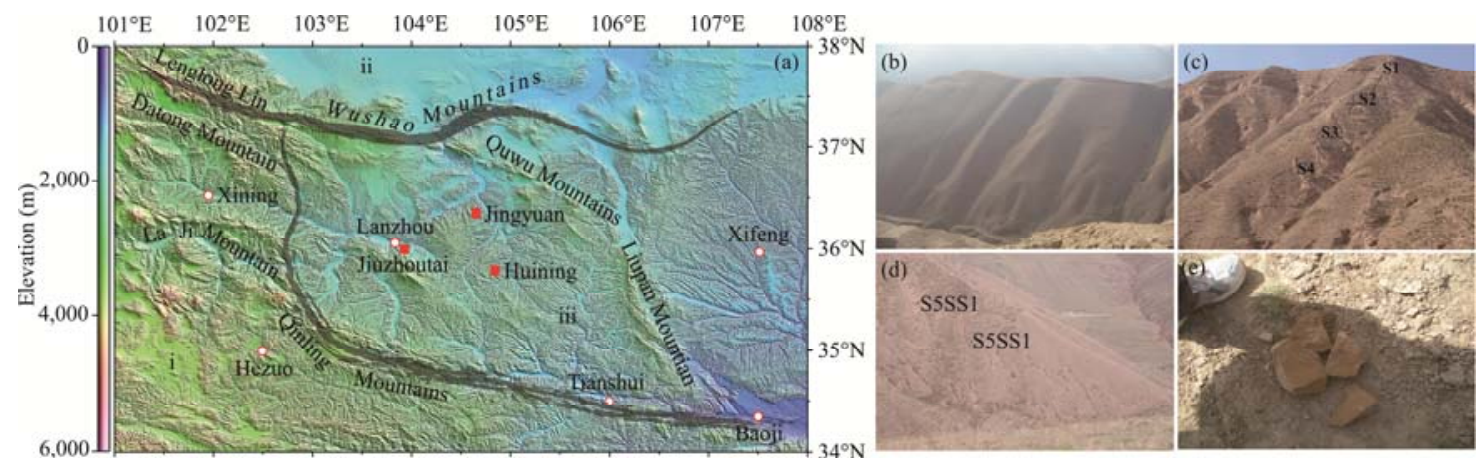

Fig. 2 The location of JY loess section investigated for this study and the natural geographic boundaries separate different regions of China. The gray line in (a) is the natural boundary of geography in China. i, ii and iii refer to the eastern monsoon area, the northwest arid area and Tibetan Plateau, respectively. (b), the landscape of the JY loess section. (c), locations of the S1-S4 paleosols in the JY loess section in the landscape. (d), locations of the S5SS1 and S5SS1 paleosols. (e), a typical S4 paleosol sampled from JY loess section. 


\subsection{Laboratory measurements}

All bulk samples were air dried in the laboratory, and analyses were carried out in the Key Laboratory of Western China's Environmental System, Ministry of Education, Lanzhou University. GS was measured with a Mastersizer 2000 (Malvern Instruments Ltd., UK), following the chemical pre-treatment procedure described by Konert and Vandenberghe (1997). The content of $\mathrm{CaCO}_{3}$ was assessed by using the Bascomb calcimeter (Bascomb, 1961). The treatment procedures are the same as those described by Fang et al. (1999). MS was measured with Bartington MS2, using the method provided by Walden et al. (1999). TOC content was determined by using the $\mathrm{H}_{2} \mathrm{SO}_{4}-\mathrm{K}_{2} \mathrm{CrO}_{7}$ oxidation method (Nelson and Sommers, 1982). The soil color was measured by using a hand-held X-Rite 948 spectrophotometer (X-Rite Co. Ltd., USA) with the $\mathrm{D}_{65}$ illuminant and a $10^{\circ}$ observational horizon. The samples were measured using the $\mathrm{L}^{*} \mathrm{a}^{*} \mathrm{~b}^{*}$ color space. Here we use the average value of three measurements for each sample.

\subsection{Climatic indicators}

At present, the MS, mean grain size (MGS) and grain size ratios, $\mathrm{CaCO}_{3}$ content, TOC content, and soil color $\left(\mathrm{L}^{*} \mathrm{a}^{*} \mathrm{~b}^{*}\right)$ are widely used as paleoclimatic proxies. Although the origins of MS enhancement in Chinese loess remain a matter of debate, there is a consensus that MS in the paleosol layers can be confidently used as a pure indicator of the intensity of the EASM (Liu, 1985; Hao and Guo, 2005). Meanwhile, the MGS and $>63 \mu \mathrm{m}$ particle content of Chinese loess have been widely used as sensitive proxies for the intensity of the EAWM (Ding et al., 1999; Sun et al., 2006). $\mathrm{CaCO}_{3}$ content was commonly used as a proxy to indicate the EASM variation in the Chinese LPS (Liu, 1985; Chen et al., 1999). In the JY section, $\mathrm{CaCO}_{3}$ is present primarily in the form of small cylinders and nodules (Yue et al., 1991), with abundant carbonate-filled and carbonate-marked grass root channels, suggesting that the carbonate is of pedogenic origin. Moreover, the content of $\mathrm{CaCO}_{3}$ in semi-arid climates is determined by available soil moisture, which is primarily precipitation-dependent (Chen et al., 1999). In this area, the precipitation is primarily carried by the EASM, and it is scarce and of relatively short duration compared with the central CLP (Yue et al., 1991). Thus, the leaching effect is limited during the warm periods and $\mathrm{CaCO}_{3}$ content can be used as a direct proxy for the EASM precipitation.

TOC content of eolian deposits was closely related to the density of vegetation in the dust depositional area (Liu and Ding, 1998). Generally, increased accumulation of TOC is apparently related to increasingly dense vegetation cover under humid climate conditions, as a result of enhanced EASM intensity (Liu et al., 2013). However, as the intensity of EASM contains temperature and precipitation signals, the TOC content reflects variations in both temperature and precipitation (Liu and Ding, 1998; Liu et al., 2013).

Color is the most visible characteristic of the soil and has recently been adopted as a new indicator of EASM (Wu et al., 2002; Sun et al., 2011; Shi et al., 2012). As indicated by recent studies, the lightness $\left(\mathrm{L}^{*}\right)$ is influenced by the content of pedogenic matter (e.g. organic matter and $\mathrm{CaCO}_{3}$ ) to varying degrees, which is related to the variations of humidity in the soil (Sun et al., 2011). Thus, $\mathrm{L}^{*}$ can act as an indicator of humidity. In contrast, the redness $\left(\mathrm{a}^{*}\right)$ is predominantly controlled by the types and concentrations of iron oxides, and primarily reflects the temperature variation on the western CLP (Shi et al., 2012).

\section{Age calibration of the JY section}

Using field observations and previous works (Yue et al., 1991; Sun et al., 2006, 2010; Shi et al., 2013), we obtained age control points (Table 1) and established a chronology for the JY LPS. Subsequently, the grain size age model described in Eq. 1 (Porter and An, 1995) was used to determine the age of the JY MGS between age control points. In general, a high MGS value corresponds to an increased capacity of wind to bear dust and a higher deposition rate (Porter and An, 1995; Ding et al., 2001). 
Table 1 Age control points and corresponding depth at JY loess section

\begin{tabular}{lccl}
\hline Unit & Position $(\mathrm{m})$ & Age control (ka) & Reference \\
\hline S0 top & 0.00 & 4.3 & Sun et al. (2010) \\
S0 base & 2.30 & 14.2 & Sun et al. (2010) \\
L1SS1 top & 11.20 & 27.7 & Sun et al. (2010) \\
L1SS1 base & 16.30 & 38.8 & Sun et al. (2010) \\
L1SS2 top & 22.70 & 48.7 & Sun et al. (2010) \\
L1SS2 base & 28.60 & 61.0 & Sun et al. (2010) \\
S1 top & 36.00 & 100.0 & Yue et al. (1991) \\
Black events & 43.10 & 110.0 & Yue et al. (1991) \\
S1 base & 46.80 & 130.0 & Yue et al. (1991) \\
S2 top & 67.80 & 189.0 & Shi et al. (2013) \\
S2 base & 79.70 & 244.0 & Shi et al. (2013) \\
S3 top & 93.00 & 280.0 & Shi et al. (2013) \\
S3 base & 102.60 & 335.0 & Shi et al. (2013) \\
S4 top & 115.70 & 362.0 & Shi et al. (2013) \\
S4 base & 128.60 & 427.0 & Shi et al. (2013) \\
S5 top & 142.30 & 470.0 & Yue et al. (1991) \\
Emperor event & 153.00 & 500.0 & Yue et al. (1991) \\
S5 base & 158.90 & 570.0 & Yue et al. (1991)
\end{tabular}
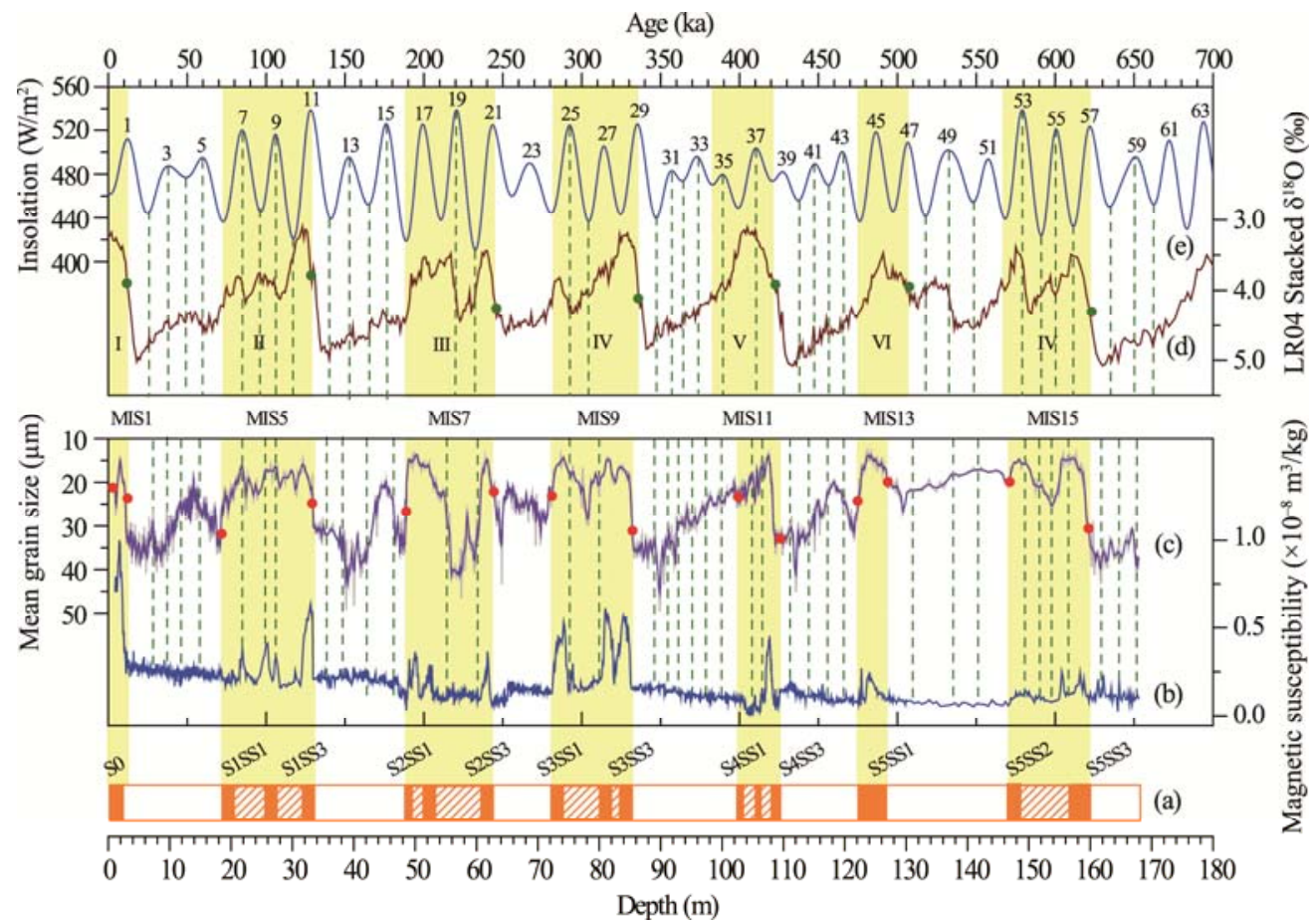

Fig. 3 Variations in JY, $65^{\circ} \mathrm{N}$ insolation in July and the LR04 stacked benthic $\delta^{18} \mathrm{O}$ values. The dashed green lines refer to insolation odd stages. Stratigraphy of the JY loess section (a). The orange rectangles are paleosols and the white rectangles are interval loess horizons. Variations in the JY MS versus depth (b). Variations in the JY MGS versus depth (c). Red dots are age control points listed in Table 1. The vertical yellow bars and red texts in (a) and (b) denote soil units. LR04 stacked benthic $\delta^{18} \mathrm{O}((\mathrm{d})$; Lisiecki and Raymo, 2005). Green dots denote terminations. The solar insolation in July at $65^{\circ} \mathrm{N}((\mathrm{e})$; Laskar et al., 2011). The vertical yellow bars denote warm intervals of the marine isotope stages. 


$$
T_{m}=T_{1}+\left(T_{2}-T_{1}\right)\left(\sum_{i=1}^{m} A_{i}^{-1}\right)\left(\sum_{i=1}^{n} A_{i}^{-1}\right) .
$$

Where $T_{m}$ is the calibrated age and $T_{1}$ and $T_{2}$ are the ages of the control points (Table 1). $A_{i}$ is the deposition rate at level $i$, which is assumed to be proportional to the MGS because both are correlated with a strong winter monsoon (Ding et al., 2001; Porter, 2001), $n$ is the total sampling level between $T_{1}$ and $T_{2}$, and $m$ is the sampling level at $T_{1}$ and $T_{2}$.

As Fig. 3 shows, the mid-point ages of the boundaries between a paleosol and its underlying loess layer are very close to those of terminations recorded in the marine record. Based on our new chronology, the average rate of eolian deposition for the JY loess section is about 0.198 $\mathrm{mm} / \mathrm{a}$ (12.9 m representing 65,000 years) during the S4 development. This rate is about three to four times higher than that on the central CLP (e.g. XF and CW sections). As discussed above, samples were obtained at intervals of $2-10 \mathrm{~cm}$ from the $\mathrm{S} 4$ paleosol, which yielded a high resolution of about $75-300 \mathrm{a} / \mathrm{cm}$.

\section{Results}

According to the soil color, texture, and multi-proxy analyses, the sub-paleosol unit S4SS3 can reasonably be correlated with MIS 11.3, and, correspondingly the unit S4SS2-S4SS1 with MIS 11.23 (Figs. 4 and 6). Unfortunately, the MIS 11.1 is difficult to identify in the JY loess section (no corresponding sub-soil developed). Based on our time scale, the paleosol S4 may have developed from 427 to $362 \mathrm{ka}$, a duration of about $65 \mathrm{ka}$. Moreover, even the duration of MIS $11.3(389-427 \mathrm{ka})$ was much longer than the present interglacial period. As Fig. 4 shows, each proxy of JY loess has a clear glacial-interglacial distribution pattern during MIS 10-12. For example, ${ }^{*}$ and $\mathrm{CaCO}_{3}$ contents are higher during the MIS 11 interglacial but lower in MIS 10 and MIS 12 glacial. In contrast, the L $^{*}$ and MGS values are higher for MIS 12 and MIS 10, but lower for MIS 11. This pattern is very similar to the previously published benthic $\delta^{18} \mathrm{O}$ records (e.g. LR04 (Lisiecki and Raymo, 2005) and MD900963 (Bassinot et al., 1994)), reflecting that the climate on the western CLP varied in phase with the global climate fluctuations during the MIS 10-12 and was therefore controlled by the global ice-volume forcing. But, the JY LPS shows more complex fluctuations than those that have been seen already in the marine record (Fig. 4), revealing much more detailed information than ever before. In addition, the JY LPS closely follows the variation of the $65^{\circ} \mathrm{N}$ insolation in July during MIS 10 and 12, revealing these two stages are also controlled by orbital climate forcing. In contrast, the variation of LPS during MIS 11 (especially in MIS 11.1-11.23) is not in phase or even out of phase with $65^{\circ} \mathrm{N}$ insolation, indicating the climate variation during the MIS 11 is not only controlled by orbital climate forcing, but also affected by other forcing in climate system, such as the disappearance of the Arctic ice cap (Hao et al., 2012) or the collapse of the south Greenland ice-sheet (Reyes et al., 2014) during this interval that may have caused the East Asian Monsoon (EAM) system to change correspondingly. Whatever the ultimate causes for this, a generally warm-humid climate clearly dominates the formation of $\mathrm{S} 4$ soil, as reflected by the higher values of ${ }^{*}$ and $\mathrm{CaCO}_{3}$ content, and the lower values of MGS and L* (Fig. 4).

Our results also show that the L5 loess (MIS 12) was deposited between 427 and $470 \mathrm{ka}$, at a relatively higher deposition rate of about $0.319 \mathrm{~mm} / \mathrm{a}$ based on our time scale. As shown in Fig. 4, L5 loess represents an extremely cold and dry glacial interval in the JY loess section, and might be the coldest and driest episode in the past $650 \mathrm{ka}$ (Fig. 5). However, it was not as severe as that indicated by the marine isotopic records (Mix et al., 1995; Shackleton et al., 1995). On the contrary, several warm stages are documented in the L5 loess as reveled by the a ${ }^{*},{ }^{*}$, MGS, and $\mathrm{CaCO}_{3}$ content, which is in good agreement with recent reports from high latitudes, such as in the South Pacific (Poli et al., 2012) and North Atlantic (King and Howard, 2000). Similarly, the L4 loess (MIS 10) also accumulated at a relatively high deposition rate (ca. $0.485 \mathrm{~mm} / \mathrm{a}$ ) between 335 and $362 \mathrm{ka}$, and the conditions during this interval were rather cold and dry. As shown in Fig. 4 , the climate fluctuated frequently and significantly like the marine sedimentary (Shackleton et 
al., 1995; Lisiecki and Raymo, 2005) and ice core records (EPICA Community Members, 2004; Pol et al., 2011), suggesting a stronger globally synchronized response.

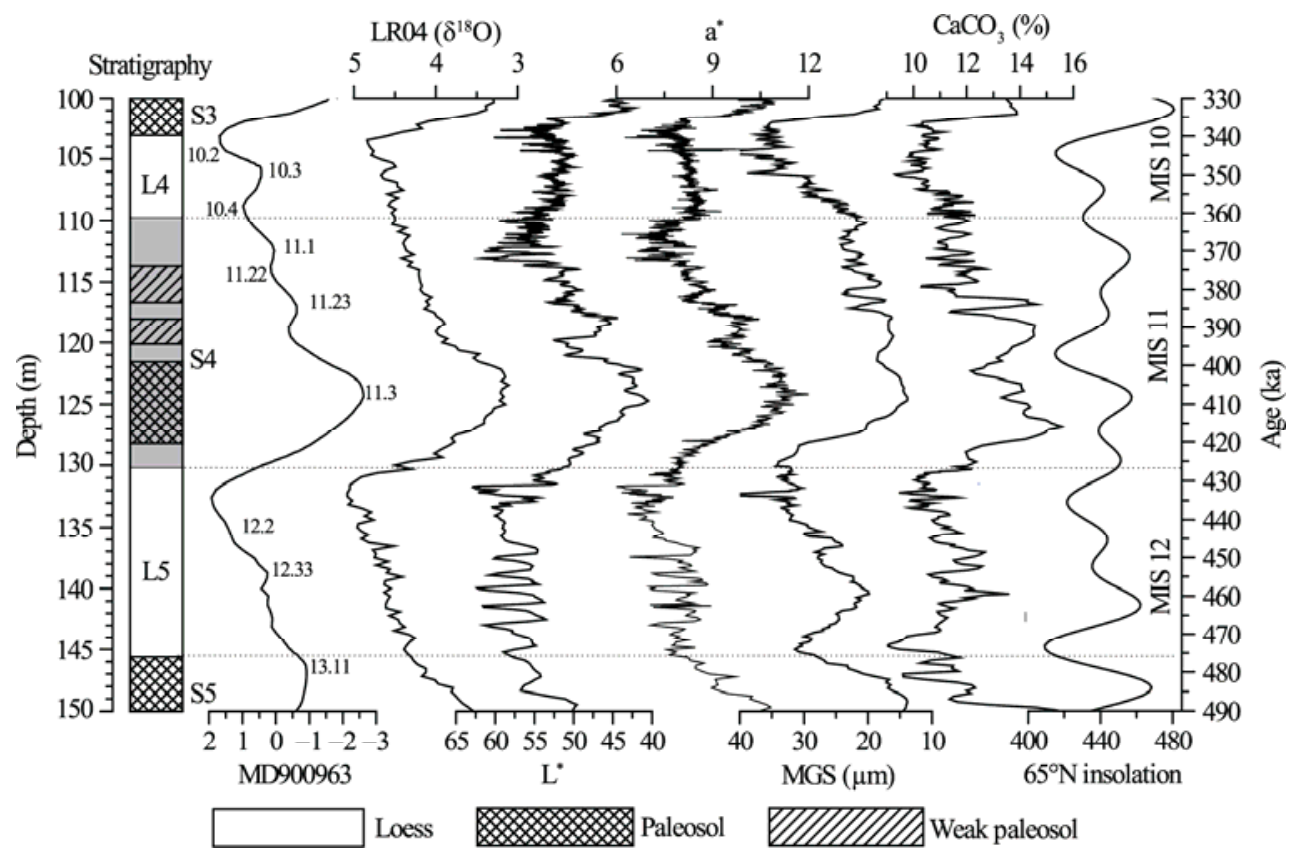

Fig. 4 Pedostratrigraphy of paleosol S4 and adjacent loess layers in the JY loess section, and variations of $\mathrm{L}^{*}$ and $\mathrm{a}^{*}, \mathrm{MGS}$, and $\mathrm{CaCO}_{3}$ content, as well as $\mathrm{MD} 900963$ benthic $\delta^{18} \mathrm{O}$ (Bassinot et al., 1994), LR04 stacked benthic $\delta^{18} \mathrm{O}$ (Lisiecki and Raymo, 2005), and solar insolation in July at $65^{\circ} \mathrm{N}$ (unit, W/m²) (Laskar et al., 2011)

\section{Discussion}

\subsection{S4 represents a relative warmer and drier episode of the past $650 \mathrm{ka}$ on the western CLP}

According to previous studies (Ding et al., 2002; Hao and Guo, 2005; Yin and Guo, 2008; Guo et al., 2009), S5 is the most prominent and well-developed paleosol on the central CLP and can be easily recognized by its thickness and dark red color. Moreover, the S5 unit also has the highest or near highest MS value. However, in the JY loess section (Fig. 5), the MS value in the S5 paleosol is in the lower range of the top six paleosols (S0-S5). In contrast, S4 is the most highly developed paleosol (Sun et al., 2006; Shi et al., 2012, 2013). The same phenomenon reported in the LZ loess section (Chen and Zhang, 1993; Chen et al., 2014) matched well with the JY loess section, indicating the MIS 11 may be the warmest intervals of the past $650 \mathrm{ka}$ on the western CLP. If the S4 paleosol in the JY section genuinely represents the warmest interglacial of the past $650 \mathrm{ka}$, then it should be reflected in those properties that are associated with the intensity of pedogenesis (e.g. MS enhancement, soil thickness, soil color, depth of decalcification, and particle size etc.). Therefore, we compared values of MS, MGS, $>63 \mu \mathrm{m}(\%), \mathrm{CaCO}_{3}$ content, TOC, $\mathrm{a}^{*}$, and $\mathrm{L}^{*}$ from $\mathrm{S} 4$ with values from the other five paleosols (S0-S3 and S5; Fig. 5). The results indicated that the climate condition during the S4 development was somewhat warmer and drier than the present-day.

As Fig. 5 shows, although the MS value in S4 was significantly lower than in S0, S1, and S3 (Fig. 5), it was greater than in S2 and S5, indicating the EASM intensity may have been weaker during the MIS 11 interval than it is now. Considering the characteristics of Monsoon climate patterns, the EASM strengthening commonly represents both the temperature rising and the precipitation increasing. Therefore, MS cannot directly indicate the temperature or precipitation change. As discussed above, ${ }^{*}$ primarily indicates the temperature variation on the western CLP. Since the highest value of $\mathrm{a}^{*}$ appeared in the S4 paleosol unit (Fig. 5), thus, the climate condition during S4 development was obviously much warmer than the present-day and even may have 
been the warmest interglacial of the past $650 \mathrm{ka}$ for the region. If this interpretation is correct, it provides strong independent support for the conclusion that the MIS 11 preserved in terrestrial archives was also the warmest interval of the past $600 \mathrm{ka}$ (Karabanov et al., 2003; Prokopenko et al., 2010), which is well consistent with the record in the marine (Shackleton et al., 1995; Howard, 1997; Lisiecki and Raymo, 2005) and ice core record (EPICA Community Members, 2004; Pol et al., 2011). Contrary to our expectations, total precipitation during the S4 paleosol development at the JY section was clearly less than those in $\mathrm{S} 1$ and $\mathrm{S} 2$ as reflected by the $\mathrm{CaCO}_{3}$ content. The amount of precipitation during the formation of S4 soil was almost the same to the S0 and S5 units (Fig. 5), indicating that the precipitation during MIS 11 was probably equivalent to that of the present-day. Furthermore, as reflected by the variation of TOC and $\mathrm{L}^{*}$ from S0 to S5, the soil humidity during the S4 paleosol development was significantly less than at present (Fig. 5). Soil humidity is closely related to the atmospheric precipitation, so it is reasonable to suppose that the climate conditions during the MIS 11 interglacial were probably drier than at present. Obviously, this conclusion contradicts those of previous studies, which proposed that many regions of the world were wetter as revealed by terrestrial archives during MIS 11 (Candy et al., 2014), except some estimations made by Desprat et al. (2005), who also suggested lower levels of rainfall existed during MIS 11 in northwestern Iberia.

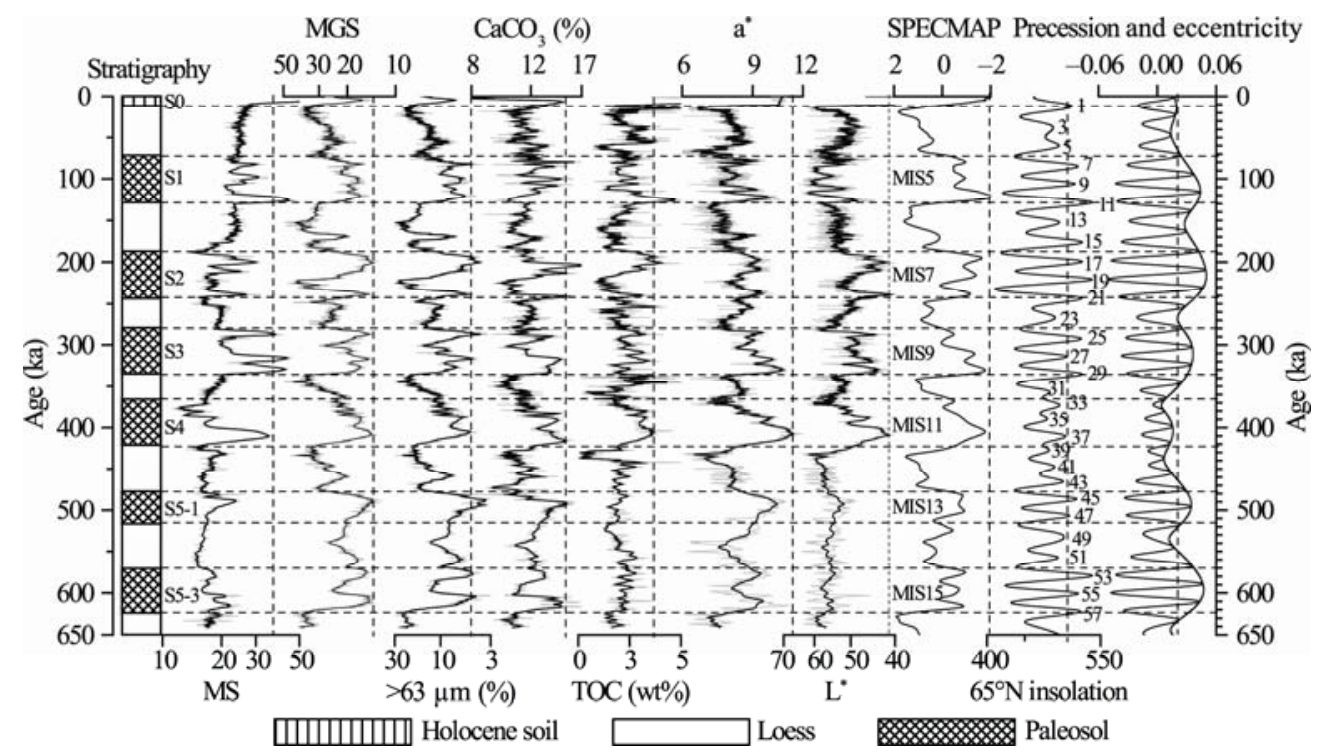

Fig. 5 Stratigraphy and variations of magnetic susceptibility (MS), MGS, $>63 \mu \mathrm{m}$ particle content, $\mathrm{CaCO}_{3}$ content, total organic carbon (TOC), $\mathrm{a}^{*}$ and $\mathrm{L}^{*}$, SPECMAP (Imbrie et al., 1984), $65^{\circ} \mathrm{N}$ insolation (Laskar et al., 2011), precession and eccentricity (Laskar et al., 2011) over the past $650 \mathrm{ka}$

Our conclusions seem to differ somewhat from those obtained from other loess sections on the CLP. For example, based on the micro-morphological comparison of paleosols and loess units with modern soils in the LC loess section, Liu (1985) suggested that the AMT and MAP were $13^{\circ} \mathrm{C}$ and $650 \mathrm{~mm}$, respectively, during the S4 paleosol development. Han et al. (1997) proposed the estimates of $11.3^{\circ} \mathrm{C}$ (AMT) and $670 \mathrm{~mm}$ (MAP) from the analyses of stable isotope composition of carbonate concentration in the LC loess section. These two studies show that the climate conditions were wetter than the present-day in the LC area (the AMT and MAP are about $13^{\circ} \mathrm{C}$ and $615 \mathrm{~mm}$, respectively). Guo et al. (1998) also assumed that the climate condition was extremely warm, with an estimated AMT of at least $6^{\circ} \mathrm{C}$ higher and MAP of 200-300 mm higher than present-day during the S4 formation from study of soil morphology, geochemistry, and MS of the XF, CW and WN loess sections. However, Vidic et al. (2003) pointed out that the climate conditions were just warm and humid during the S4 paleosol formation based on the pedogenic intensity and other proxies obtained from the JD loess section. Wu et al. (2007) recently proposed 
that the early part of the S4 development (ca. $30 \mathrm{ka}$ ) was warmer and more humid than the Holocene, whereas the later part of the MIS 11 was similar, or cooler, based on mollusk analyses from the XF and LC LPS. Therefore, remarkable regional differences existed on the CLP during MIS 11 interglacial. The mechanism of this distribution pattern is not totally explained and further detailed studies are still required.

\subsection{The climate condition is unstable during S4 paleosol development on the western CLP}

MIS 11 is generally regarded as a relatively stable "super-interglacial" on the basis of climate simulations (Loutre, 2003; Kleinen et al., 2014) and paleoclimatic reconstruction (Howard, 1997; Droxler et al., 2003a; Candy et al., 2014). Similarly, it is commonly assumed as well that the climate was warm and stable during the S4 development on the central CLP, as reflected in the unimodal character of the MS and GS distribution (Guo et al., 2000; Hao and Guo, 2005). In the JY loess section, the climatic conditions were not uniform throughout the paleosol S4 development. As revealed by the proxy of MS, $\mathrm{L}^{*}, \mathrm{a}^{*}, \mathrm{MGS},>63 \mu \mathrm{m}$ particle content, TOC, and $\mathrm{CaCO}_{3}$ content (Fig. 6), the early part of S4, a period of $37 \mathrm{ka}$, was rather warm and humid, whereas the later part was characterized by mild to fairly cold (but not glacial) conditions. Thus, the S4 paleosol clearly developed under two different climate regimes, which varied from a rather warm and humid early stage to a relatively mild to colder (but not glacial) later stage. This conclusion supports previous findings that the climate experienced differing regimes during the MIS 11 interglacial on the central CLP (Wu et al., 2007; $\mathrm{Wu}$ and $\mathrm{Lu}, 2012$ ). So we suggest that the climate was generally unstable during the whole of MIS 11 period in the JY area of the western CLP, which was also in agreement with the findings of Droxler et al. (2003b) obtained from the JD loess section. However, if we separate the MIS 11 interglacial into two parts, we can find that the climate was extremely stable during the early part of MIS 11.3 (corresponding to S4SS3) as reflected by the relatively "smoothed" curve of proxies, but relatively unstable during the latter part of the MIS 11 (corresponding to S4SS2 and S4SS1) indicated by the dramatically oscillation of proxies (Fig. 6). Despite the distinct regional differences found in response of the climate change across the CLP, the stable early part of the S4 paleosol development was also recorded in the LC and XF loess sections (Wu et al., 2007; Wu and $\mathrm{Lu}, 2012$ ). Therefore, we concluded that the climate conditions were extremely stable during the early part of MIS 11 over the CLP.

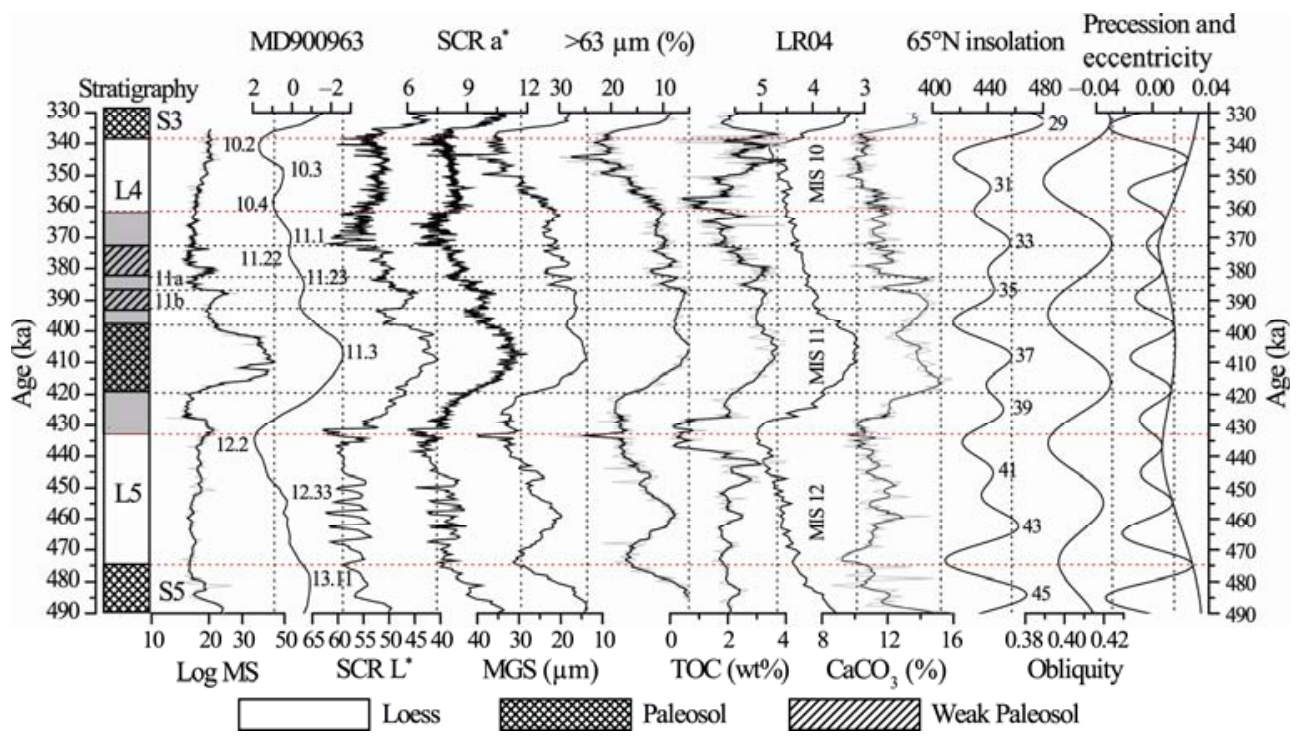

Fig. 6 Pedostratrigraphy of paleosol S4 and adjacent units showing variations in $\mathrm{MS}, \mathrm{L}^{*}$ and a* $>63 \mu \mathrm{m}$ particle content, MGS, TOC, $\mathrm{CaCO}_{3}$ content, as well as MD900963 benthic $\delta^{18} \mathrm{O}$ (Bassinot et al., 1994), LR04 stacked benthic $\delta^{18} \mathrm{O}$ (Lisiecki and Raymo, 2005), $65^{\circ} \mathrm{N}$ summer insolation (Laskar et al., 2011) and orbital parameters (obliquity, precession and eccentricity); the MS was log-transformed for clarity. 
Further analysis in Fig. 6 shows that the highest or lowest values of the geophysical and geochemical proxies during the MIS 11.3 not only corresponds well to $65^{\circ} \mathrm{N}$ insolation (Laskar et al., 2011) odd stages (IOS), but are also consistent with the lowest values of the marine stacked $\delta^{18} \mathrm{O}$ record (Bassinot et al., 1994; Lisiecki and Raymo, 2005). In contrast, during the latter part of the MIS 11, the proxies do not well match the insolation or marine $\delta^{18} \mathrm{O}$ records. This suggests that a stronger climate forcing may have existed, which dominated climate change during the development of S4SS3 paleosol. In contrast, this climate forcing became weaker and other regional climate forcing became gradually stronger during the S4SS2-S4SS1 development, which caused the climate to be extremely warm and stable in the early part of MIS 11, and relatively cooler and unstable during the latter part of MIS 11. In order to identify this potentially stronger climate forcing, we further used the wavelet analysis method, which has been shown to be very useful in analysis of geophysical time series (Torrence and Compo, 1998). As Fig. 7 shows, climate change around $400 \mathrm{ka}$ was primarily dominated by eccentricity and eccentricity modulated precession. Further analysis confirmed that the quasi-100-ka cycle, which is far more frequent than the eccentricity cycles of $413 \mathrm{ka}$ and precession, dominated the climate variability throughout the MIS 11 interglacial. Although there were several smaller millennial-scale climate fluctuations, it appears that this stronger climate forcing was superimposed on other climate forcing during the early part of MIS 11 and kept the climate stable. This result contradicts the previous conclusion that the quasi-19 ka climate forcing dominated the climate change during MIS 11 interglacial at the LC loess section (Wu and Lu, 2012). Liu et al. (1999) suggested that the climate cycles were $100,41,23$ and $19 \mathrm{ka}$ during the period of $0.0-0.6 \mathrm{Ma}$; therefore, the quasi-100-ka cycle might be related to the eccentricity cycles. In addition, the quasi-100-ka cycle climate forcing may have affected the $65^{\circ} \mathrm{N}$ insolation in July and thus controlled the climate variation during the early part of MIS 11 (Fig. 7h). Although the Milankovitch theory cannot explain how the MIS 11 interglacial occurred (Loutre and Berger, 2003; Kleinen et al., 2014), we still assumed that the quasi-100-ka cycle dominated the climate variability during this interglacial by modulating variations in $65^{\circ} \mathrm{N}$ insolation. Moreover, the stable climate conditions during MIS 11.3 at JY loess is also apparent at Lake El'gygytgyn (Vogel et al., 2013), Lake Baikal (Karabanov et al., 2003; Prokopenko et al., 2010) and in the EDC ice core record (EPICA Community Members, 2004; Pol et al., 2011). Therefore, it is possible that the climate forcing identified in this study was globally significant, and have maintained the climate change with the same rhythm in nearly all marine and terrestrial records during the early part of MIS 11.

On the other hand, the climatic oscillations were more frequent and complicated during the latter part of MIS 11. As shown in Fig. 6, each proxy in the JY LPS shows distinctly different variations and does not match well with the marine stacked $\delta^{18} \mathrm{O}$ records and $65^{\circ} \mathrm{N} \operatorname{IOS}$, indicating that the climate forcing and response mechanisms were not the same for each proxy during this interval. Together with wavelet analysis (Fig. 7), we concluded that the quasi-100-ka climate forcing and regional climate forcing both dominated the climate variations during the latter part of MIS 11. Although the quasi-100-ka climate forcing still played an important role in affecting the climate change, it has become gradually weaker during the S4SS2-S4SS1 development and was unable to override the regional climate forcing as it did during the early part of MIS 11. As shown in Fig. 7, there was not only a quasi-100-ka period, but also many millennial-scale periods. The JY area is located at the transition zone of the eastern monsoon area, northwest arid area, and TP (Fig. 2); therefore, the millennial climate forcing may be not only related to the EAM, but also related to the westerly and Indian monsoon. However, based on our currently available method and loess records, we cannot directly determine what forces these millennial-scale climate variations. Further analysis and additional high-resolution terrestrial archives are urgently required to carry out. 

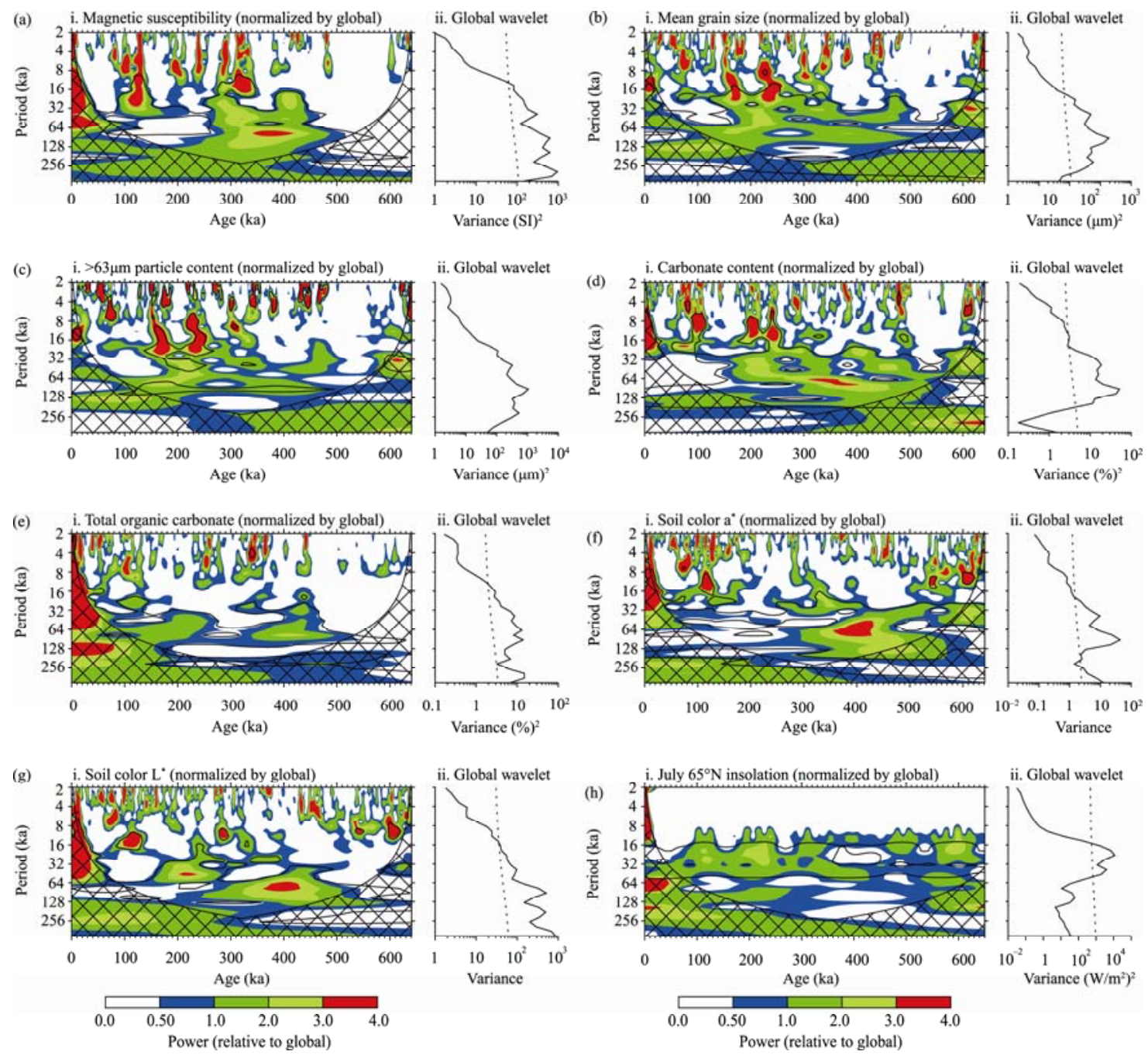

Fig. 7 Wavelet power spectrum (Torrence and Compo, 1998) of (a) MS, (b) MGS, (c) $>63 \mu \mathrm{m}$ particle content, (d) $\mathrm{CaCO}_{3}$ content, (e) TOC, (f) a ${ }^{*},(\mathrm{~g}) \mathrm{L}^{*}$ and (h) $65^{\circ} \mathrm{N}$ insolation in July (Laskar et al., 2011) . The contour level intervals were chosen so that $75 \%, 50 \%, 25 \%$, and $5 \%$ of the wavelet power is above each level. The cross-hatched region is the cone of influence, where zero padding has reduced the variance. The black contour shows the $10 \%$ significance level, based on a red-noise (autoregressive lag) background spectrum. The dashed green lines indicate the $95 \%$ confidence level.

\section{Conclusion}

In this work, we studied the S4 paleosol in the thickest known JY section on the western margin of the CLP, and focused on the climate conditions, warmth, and stability during the formation of S4 soil. Compared with the S5 unit, the highest developed paleosol on the central CLP, the S4 paleosol is the highly developed soil on the western CLP with higher MS values, a dark red color, and great thickness. Based on high-resolution sampling and detailed laboratory analysis, we established an updated chronology for the upper part of L6 to the mordent soil by applying a grain-size age model. This enabled us to produce a precise interpretation of the climatic conditions that prevailed on the western CLP during MIS 11. Our results show that the S4 paleosol development spanned from 427 to $362 \mathrm{ka}$, which was longer than the present interglacial (Holocene) and other interglacials during the past 650ka. Even the early part of S4 (MIS 11.3) was longer than present-day. Moreover, the high-resolution multi-proxy record of the JY LPS indicates that a generally warm-humid climatic condition dominated the S4 paleosol development, 
but the climate condition was extremely unstable during the whole of MIS 11 interglacial. Two obviously different climate regimes controlled the MIS 11 climate variation: the early part of MIS 11 was extremely warm and stable, but the latter part was relatively cool (non-glacial) and unstable.

Wavelet analysis indicated that a quasi-100-ka cycle may have driven the early MIS 11.3 variations and maintained climate stability by modulating $65^{\circ} \mathrm{N}$ insolation. This climate forcing is so strong as to superimpose on other regional climate forcing and make the climate condition keep the same rhythm through the whole CLP. Moreover, the quasi-100-ka climate forcing identified in this study might be globally significant, because the structure of MIS 11.3 in the JY loess shows similar characteristics to the records from lake, marine, and ice cores. In contrast, due to the quasi-100-ka cycle and other regional climate forcing both dominating the climate change, the climate conditions were more complicated and unstable during the latter part of MIS 11. As a result of the methods used in this work and our reliance on a single loess record, we were unable to identify the source of the regional climate forcing. Therefore, more detailed analysis and study of additional high-resolution loess sections must be the focus of future studies.

In addition, multi-proxy comparative study on the climate conditions during paleosol S0 to S5 development indicates that the period of S4 development might be the warmest interglacial of the past $650 \mathrm{ka}$. However, the climate condition during this period was not the most humid as recorded in the XF and LC loess sections on the central CLP. On the contrary, it was drier than both the MIS 15 and the present interglacial on the western CLP, which is somewhat similar to the present climate pattern around the central CLP.

\section{Acknowledgements}

This work was joint supported by the National Natural Science Foundation of China $(41401226,41271024)$ and the China Postdoctoral Science Foundation (2015M570865). We thank Dr. XU Shanyang, DENG Shaofu and ZHANG Junhui for field investigation, sample collection and laboratory assistance. We are also grateful to the anonymous reviewer for providing useful comments, which helped to improve the manuscript.

\section{References}

Ashton N, Lewis S G, Parfitt S A, et al. 2008. New evidence for complex climate change in MIS 11 from Hoxne, Suffolk, UK. Quaternary Science Reviews, 27(7-8): 652-668.

Bascomb C L. 1961. A calcimeter for routine use on soil samples. Chemistry and Industry, 45: 1826-1827.

Bassinot F C, Beaufort L, Vincent E, et al. 1994. Coarse fraction fluctuations in pelagic carbonate sediments from the tropical Indian Ocean: A 1500-kyr record of carbonate dissolution. Paleoceanography, 9(4): 579-600.

Bauch H A, Erlenkeuser H, Helmke J P, et al. 2000. A paleoclimatic evaluation of marine oxygen isotope stage 11 in the high-northern Atlantic (Nordic Seas). Global and Planetary Change, 24(1): 27-39.

Candy I, Schreve D C, Sherriff J, et al. 2014. Marine Isotope Stage 11: palaeoclimates, palaeoenvironments and its role as an analogue for the current interglacial. Earth-Science Reviews, 128: 18-51.

Chen F H, Zhang W X. 1993. The Loess Stratigraphy and Quaternary Glacial Problems in the Areas of Gansu Province and Qinghai Province. Beijing: Science Press. (in Chinese)

Chen F H, Bloemendal J, Feng Z D, et al. 1999. East Asian monsoon variations during oxygen isotope stage 5: evidence from the northwestern margin of the Chinese Loess Plateau. Quaternary Science Reviews, 18(8-9): 1127-1135.

Chen F H, Qiang M R, Feng Z D, et al. 2003. Stable East Asian monsoon climate during the Last Interglacial (Eemian) indicated by paleosol S1 in the western part of the Chinese Loess Plateau. Global and Planetary Change, 36(3): 171-179.

Chen J S, Liu X M, Kravchinsky V A. 2014. Response of the high-resolution Chinese loess grain size record to the $50^{\circ} \mathrm{N}$ integrated winter insolation during the last 500,000 years. Geophysical Research Letters, 41(17): 6244-6251.

Derbyshire E, Meng X M, Kemp R A. 1998. Provenance, transport and characteristics of modern Aeolian dust in western Gansu province, China, and interpretation of the Quaternary loess record. Journal of Arid Environments, 39(3): 497-516.

Desprat S, Sánchez Goñi M F, Turon J L, et al. 2005. Is vegetation responsible for glacial inception during periods of muted insolation changes? Quaternary Science Reviews, 24(12-13): 1361-1374.

Ding Z L, Liu T S, Rutter N W, et al. 1995. Ice-volume forcing of East Asian winter monsoon variations in the past 800,000 years. Quaternary Research, 44(2): 149-159. 
Ding Z L, Sun J M, Rutter N W, et al. 1999. Changes in sand content of loess deposits along a north-south transect of the Chinese Loess Plateau and the implications for desert variations. Quaternary Research, 52(1): 56-62.

Ding Z L, Yu Z W, Yang S L, et al. 2001. Coeval changes in grain size and sedimentation rate of eolian loess, the Chinese Loess Plateau. Geophysical Research Letters, 28(10): 2097-2100.

Ding Z L, Derbyshire E, Yang S L, et al. 2002. Stacked 2.6-Ma grain size record from the Chinese loess based on five sections and correlation with the deep-sea $\delta^{18} \mathrm{O}$ record. Paleoceanography, 17(3): 5-1-5-21.

Droxler A W, Alley R B, Howard W R, et al. 2003a. Unique and exceptionally long interglacial Marine Isotope Stage 11: window into Earth warm future climate. In: Droxler A W, Poore R Z, Burckle L H. Earth's Climate and Orbital Eccentricity: The Marine Isotope Stage 11 Question. Washington D C: American Geophysical Union, 1-14.

Droxler A W, Poore R Z, Burckle L H. 2003b. The Chinese loess perspective on Marine Isotope Stage 11 as an extreme interglacial. In: Vidic N J, Verosub K L, Singer M J. Earth's Climate and Orbital Eccentricity: The Marine Isotope Stage 11 Question. Washington, DC: American Geophysical Union, 231-240.

EPICA Community Members. 2004. Eight glacial cycles from an Antarctic ice core. Nature, 429(6992): $623-628$.

Fang X M, Ono Y, Fukusawa H, et al. 1999. Asian summer monsoon instability during the past 60,000 years: magnetic susceptibility and pedogenic evidence from the western Chinese Loess Plateau. Earth and Planetary Science Letters, 168(3-4): 219-232.

Guo Z T, Liu T, Fedoroff N, et al. 1998. Climate extremes in Loess of China coupled with the strength of deep-water formation in the North Atlantic. Global and Planetary Change, 18(3-4): 113-128.

Guo Z T, Biscaye P, Wei L Y, et al. 2000. Summer monsoon variations over the last 1.2 Ma from the weathering of loess-soil sequences in China. Geophysical Research Letters, 27(12): 1751-1754.

Guo Z T, Berger A, Yin Q Z, et al. 2009. Strong asymmetry of hemispheric climates during MIS-13 inferred from correlating China Loess and Antarctica ice records. Climate of the Past, 5(1): 21-31.

Han J M, Keppens E, Liu T, et al. 1997. Stable isotope composition of the carbonate concretion in loess and climate change. Quaternary International, 37: 37-43.

Hao Q Z, Guo Z T. 2005. Spatial variations of magnetic susceptibility of Chinese loess for the last 600 kyr: implications for monsoon evolution. Journal of Geophysical Research, 110(B12), doi: 10.1029/2005JB003765.

Hao Q Z, Wang L, Oldfield F, et al. 2012. Delayed build-up of arctic ice sheets during 400,000-year minima in insolation variability. Nature, 490(7420): 393-396.

Heslop D, Shaw J, Bloemendal J, et al. 1999. Sub-millennial scale variations in East Asian monsoon systems recorded by dust deposits from the North-western Chinese Loess Plateau. Physics and Chemistry of the Earth, Part A: Solid Earth and Geodesy, 24(9): 785-792.

Heslop D, Langereis C G, Dekkers M J. 2000. A new astronomical timescale for the loess deposits of Northern China. Earth and Planetary Science Letters, 184(1): 125-139.

Hodell D A, Charles C D, Ninnemann U S. 2000. Comparison of interglacial stages in the South Atlantic sector of the southern Ocean for the past $450 \mathrm{kyr}$ : implifications for Marine Isotope Stage (MIS) 11. Global and Planetary Change, 24(1): 7-26.

Howard W R. 1997. Palaeoclimatology: a warm future in the past. Nature, 388(6641): 418-419.

Imbrie J, Hays J D, Martinson D G, et al. 1984. The orbital theory of Pleistocene climate: support from a revised chronology of the marine $\delta^{18} \mathrm{O}$ record. In: Berger A. Milankovitch and Climate, Part 1. Netherlands: Springer, 269-305.

Karabanov E, Prokopenko A, Williams D, et al. 2003. High-Resolution MIS 11 record from the continental sedimentary archive of lake baikal, Siberia. In: Droxler A W, Poore R Z, Burckle L H. Earth's Climate and Orbital Eccentricity: The Marine Isotope Stage 11 Question. Geophysical Monograph, Vol. 137. Washington, DC: American Geophysical Union, 223-230.

King A L, Howard W R. 2000. Middle Pleistocene sea-surface temperature change in the southwest Pacific Ocean on orbital and suborbital time scales. Geology, 28(7): 659

Kleinen T, Hildebrandt S, Prange M, et al. 2014. The climate and vegetation of Marine Isotope Stage 11-Model results and proxy-based reconstructions at global and regional scale. Quaternary International, 348: 247-265.

Konert M, Vandenberghe J E F. 1997. Comparison of laser grain size analysis with pipette and sieve analysis: a solution for the underestimation of the clay fraction. Sedimentology, 44(3): 523-535.

Laskar J, Fienga A, Gastineau M, et al. 2011. La2010: a new orbital solution for the long-term motion of the Earth. Astronomy \& Astrophysics, 532(A89), doi: 10.1051/0004-6361/201116836.

Lisiecki L E, Raymo M E. 2005. A pliocene-pleistocene stack of 57 globally distributed benthic $\delta^{18} \mathrm{O}$ records. Paleoceanography, 20(1): PA1003.

Liu G, Liu P L, Yang M Y, et al. 2013. The significance and relationships among substitutive climatic proxies in the Holocene at the middle Loess Plateau in China. Environmental Earth Sciences, 70(7): 2997-3004. 
Liu T S. 1985. Loess and the Environment. Beijing: China Ocean Press. (in Chinese)

Liu T, Ding Z L. 1998. Chinese loess and the paleomonsoon. Annual Review of Earth and Planetary Sciences, 26: 111-145.

Liu T, Ding Z L, Rutter N. 1999. Comparison of Milankovitch periods between continental loess and deep sea records over the last 2.5 Ma. Quaternary Science Reviews, 18(10-11): 1205-1212.

Loutre M F. 2003. Clues from MIS 11 to predict the future climate-a modelling point of view. Earth and Planetary Science Letters, 212(1-2): 213-224.

Loutre M F, Berger A. 2003. Marine Isotope Stage 11 as an analogue for the present interglacial. Global and Planetary Change, 36(3): 209-217.

Mix A C, Pisias N G, Rugh W, et al. 1995. Benthic foraminifer stable isotope record from Site 849 (0-5 Ma): local and global climate changes. In: Pisias N G, et al. Proceedings of the Ocean Drilling Program, Scientific Results, Volume 138. Ocean Drilling Program, 371-412.

Nelson D W, Sommers L E. 1982. Total carbon, organic carbon and organic matter. In: Page A L, Miller R H, Keeney D R. Methods of Soil Analysis ( $2^{\text {nd }}$ ed). Madison: American Society of Agronomy, 535-567.

Pol K, Debret M, Masson-Delmotte V, et al. 2011. Links between MIS 11 millennial to sub-millennial climate variability and long term trends as revealed by new high resolution EPICA Dome $\mathrm{C}$ deuterium data-a Comparison with the Holocene. Climate of the Past, 7(2): 437-450.

Poli M S, Meyers P A, Thunell R C, et al. 2012. Glacial-interglacial variations in sediment organic carbon accumulation and benthic foraminiferal assemblages on the Bermuda Rise (ODP Site 1063) during MIS 13 to 10. Paleoceanography, 27(3): PA3216.

Porter S C, An Z S. 1995. Correlation between climate events in the North Atlantic and China during the last glaciation. Nature, 375(6529): 305-308.

Porter S C. 2001. Chinese loess record of monsoon climate during the last glacial-interglacial cycle. Earth-Science Reviews, 54(1-3): 115-128.

Prokopenko A A, Bezrukova E V, Khursevich G K, et al. 2010. Climate in continental interior Asia during the longest interglacial of the past 500000 years: the new MIS 11 records from Lake Baikal, SE Siberia. Climate of the Past, 6(1): $31-48$.

Reyes A V, Carlson A E, Beard B L, et al. 2014. South Greenland ice-sheet collapse during Marine Isotope Stage 11. Nature, 510(7506): 525-528.

Shackleton N J, Hall M A, Pate D. 1995. Pliocene Stable Isotope Stratigraphy of ODP Site 846. In: Proceedings of the Ocean Drilling Program, Scientific Results, Volume 138. Ocean Drilling Program, 337-355.

Shi P H, Yang T B, Tian Q C, et al. 2012. Chroma chracteristics in the loess-paleosol at Jingyuan section and its signification to paleocliamete. Journal of Lanzhou University (Natural Sciences), 48(2): 15-23. (in Chinese)

Shi P H, Yang T B, Tian, Q C, et al. 2013. Loess record of climatic changes during MIS 12-10 in the Jingyuan section, northwestern Chinese Loess Plateau. Quaternary International, 296: 149-159.

Stocker T F, Qin D H, Plattner G K, et al. 2013. Climate change 2013: the physical science basis. In: Working Group I Contribution to the Fifth Assessment Report of the Intergovernmental Panel on Climate Change. Cambridge, United Kingdom and New York: Cambridge University Press.

Sun Y B, Chen J, Clemens S C, et al. 2006. East Asian monsoon variability over the last seven glacial cycles recorded by a loess sequence from the northwestern Chinese Loess Plateau. Geochemistry, Geophysics, Geosystems, 7: Q12Q02.

Sun Y B, Wang X L, Liu Q S, et al. 2010. Impacts of post-depositional processes on rapid monsoon signals recorded by the last glacial loess deposits of Northern China. Earth and Planetary Science Letters, 289(1-2): 171-179.

Sun Y B, He L, Liang L J, et al. 2011. Changing color of Chinese loess: geochemical constraint and paleoclimatic significance. Journal of Asian Earth Sciences, 40(6): 1131-1138.

Torrence C, Compo G P. 1998. A practical guide to wavelet analysis. Bulletin of the American Meteorological Society, 79(1): $61-78$.

Tzedakis P C. 2010. The MIS 11-MIS 1 Analogy, Southern European Vegetation, Atmospheric Methane and the "Early Anthropogenic Hypothesis". Climate of the Past, 6(2): 131-144.

Vidic N J, Verosub K L, Singer M J. 2003. The Chinese loess perspective on Marine Isotope Stage 11 as an extreme interglacial. In: Droxler A W, Poore R Z, Burckle L H. Earth's Climate and Orbital Eccentricity: The Marine Isotope Stage 11 Question. Washington, DC: American Geophysical Union, 231-240.

Vogel H, Meyer-Jacob C, Melles M, et al. 2013. Detailed insight into arctic climatic variability during MIS 11c at Lake El'gygytgyn, NE Russia. Climate of the Past, 9(4): 1467-1479.

Walden F, Oldfield F, Smith J. 1999. Environmental magnetism: a practical guide. Technical Guide No. 6. London: Quaternary 
Research Association, 35-62.

Wu G J, Pan B T, Guan Q Y, et al. 2002. Loess record of climatic changes during MIS5 in the Hexi Corridor, Northwest China. Quaternary International, 97-98: 167-172.

Wu N Q, Chen X Y, Rousseau D D, et al. 2007. Climatic conditions recorded by terrestrial mollusc assemblages in the Chinese Loess Plateau during marine Oxygen Isotope Stages 12-10. Quaternary Science Reviews, 26(13-14): 1884-1896.

Wu T N, Lu G Y. 2012. Climatic sub-cycles recorded by the fourth paleosol layer at Luochuan on the Loess Plateau. Environmental Earth Sciences, 66(5): 1329-1335.

Yin Q Z, Guo Z T. 2008. Strong summer monsoon during the cool MIS-13. Climate of the Past, 4(1): $29-34$.

Yue L P, Lei X Y, Qu H J. 1991. A magnetostratigraphic study on the Jingyuan loess section, Gansu, China. Quaternary Sciences, 11(4), 349-353. (in Chinese) 